\title{
Komparatystyka
}

\section{DWA MITY A DWIE FORMACJE KULTUROWE (W PORÓWNANIU)}

\author{
LIDIA WIŚNIEWSKA ${ }^{1}$ \\ (Uniwersytet Kazimierza Wielkiego w Bydgoszczy)
}

Słowa kluczowe: mity i paradygmaty, modernizm i postmodernizm, ciągi formacyjne Key words: myths and paradigms, modernism and postmodernism, formation chaines

\begin{abstract}
Abstrakt: Lidia Wiśniewska, DWA MITY A DWIE FORMACJE KULTUROWE (W PORÓWNANIU). „PORÓWNANIA” 19, 2016. T. XIX. S. 9-20. ISSN 1733-165X. Przywołujący koncepcje Jaussa, Vattimo, Lasha i Steinera artykuł Dwa mity a dwie formacje kulturowe (w porównaniu) sygnalizuje wprawdzie ponaddziedzinowy charakter obserwacji, ale skupia się przede wszystkim na łączności dwu mitów (Boga i Natury, nazywanych tu także mitami nowoczesnym i archaicznym, oraz odpowiadających im paradygmatów - linearnego i cyrkularnego) z charakterystykami dwu formacji/epok, mianowicie modernizmu i postmodernizmu. Wiąże to z możliwościami rekonstrukcji łączących te (dawne) mity i (współczesne) epoki dwu linii czy też (przerywanych, ale i przeplatających się) "ciągów formacyjnych" zdeterminowanych przez określone sposoby traktowania kategorii czasu i przestrzeni we wspomnianych mityczno-paradygmatycznych wzorcach poznawczych.
\end{abstract}

Abstract: Lidia Wiśniewska, TWO MYTHS AND TWO CULTURAL FORMATIONS (IN COMPARISON). "PORÓWNANIA" 19, 2016. Vol. XIX. P. 9-20. ISSN 1733-165X. The article Two Myths and Two Cultural Formations (in comparison) that recalls Jauss's, Vattimo's, Lash's and Steiner's concepts and indicates too a trans-discipline nature of observation is in the first place focused on the unity between the two myths (God's and Nature's ones, also named as modern and archaic myths, and the related paradigms: linear and circular) and the description of the two formations/ /epochs, that is modernism and postmodernism. This entails a possible reconstruction of two lines to unite the (early) myths and (contemporary) epochs or the reconstruction of the "formation sequences"(dashed and interwoven) determined by the defined methods of how the time and space categories are treated in the described myth and paradigm cognitive patterns.

1 E-mail: wisli@poczta.onet.pl 
Przyznając się do zakotwiczenia własnych poglądów w tezie o oddzieleniu Natury i Cywilizacji przez mieszczaństwo doby oświecenia otwierającym drogę do postępu "rozumu instrumentalnego", czego konsekwencje znaleźć można w modernizmie od połowy XIX w. - tezie obecnej w Dialektyce oświecenia Theodora Adorna i Maxa Horkheimera - Robert Jauss (Jauss 27) łączy postmodernizm (i towarzyszące mu inne zjawiska, jak posthistorię, postpatriarchalizm, postindustrializm, postkomuninizm, postkapitalizm czy poststrukturalizm) z (neo)konserwatyzmem, domagającym się powrotu do idei kontrkultury i tradycji, a zarazem zwraca uwagę, że wszystko to oznacza przeciwstawienie się modernie z jej wyznacznikami w postaci logocentryzmu tudzież awangard jako grup wskazujących nowe drogi i kierunki (Jauss 21). Tak postrzeganą przez pryzmat walki Starego i Nowego współczesność wpisuje jednak w całą europejską kulturę przedstawianą przez niego jako nieustanny spór Starego i Nowego, począwszy od radykalnego zniesienia całej przeszłości grecko-rzymskiej w geście otwarcia nowej ery post Christum natum (co podkreślają słowa św. Pawła: „Spójrz, wszystko stało się nowe!” - wyróżn. L.W.), poprzez chrześcijańskie po- czy też odnowienie słowa modernus, jakie pojawia się u św. Augustyna $\mathrm{w} \mathrm{V}$ w. n.e., a następnie przez reformację aż po manifesty nowych ruchów politycznych, a w końcu także „rewolucje estetyczne” - którego to sformułowania użyli Friedrich Schiller i Friedrich Schlegel.

Wpisuje on zatem modernizm i postmodernizm w dwie linie formacyjne, które wyznaczane są zarówno przez wewnętrzne różnicowanie w ramach jednej tradycji judeochrześcijańskiej (między Starym a Nowym Testamentem, a potem w ramach nowotestamentowego podejścia między katolicyzmem a reformacją, choć nie wspomina już o różnych ruchach heretyckich), jak i przez opozycje zewnętrzne - między tradycją judeochrześcijańską a grecko-rzymską. W przypadku tej ostatniej, nawiasem mówiąc, nie wskazuje wewnętrznych opozycji, choć nie jest trudno takie wyznaczyć - by przypomnieć wewnętrzną antynomię wobec apologii życia doczesnego choćby pierwiastków orfickich, które Adam Krokiewicz wydobywa w motywie wysp szczęśliwych i niechęci do bytowania cielesnego oraz apoteozie nieśmiertelnej duszy u Hezjoda (Krokiewicz 57), czy dostrzeżenie przez Vernanta w Grecji pierwiastka duchowego spokrewnionego z boskością i tęskniącego za powrotem do niej poprzez oddzielenie się od ciała (Vernant 99). Znacznie wcześniej Nietzsche wskazywał zaś taki spór wewnętrzny w opozycji postawy apollińskiej i dionizyskiej poczynając od Homera i Archilocha (Nietzsche 1907: 48).

U podstaw śledzenia opisywanego przez Jaussa ciągu opozycji można postawić jednak przede wszystkim zewnętrzną opozycję mitu (judeo)chrześcijańskiego i mitu archaicznego (który z kolei w punkcie dojścia wyraźnie ujawni się w kontrkulturze zauroczonej archaicznymi mitami Dalekiego Wschodu z ich kołowym nawrotem w czasie oraz Naturą jako niosącą wolność opozycją wobec reguł nowoczesności). Lecz nie sposób nie dostrzec, iż od pewnego momentu w tym ciągu sporów zastępuje ją opozycja o charakterze nie mitycznym a paradygmatycznym, obejmu- 
jąca politykę, naukę czy sztukę (choć, jak sądzi autor, estetyczna rewolucja końca XVIII wieku domaga się uznania idei piękna za Nową Mitologię - por. Jauss 40). Oczywiście Jauss nie tylko mówi przy tym o ostrych opozycjach, które kumulują się w odsuwaniu Starego przez Nowe, ale także wskazuje na sploty czy zawiłości obu elementów wprowadzające na przykład legitymizację Nowego przez Stare, co zresztą realizuje się zarówno na poziomie mitycznym, jak i paradygmatycznym, skoro przypominając o obecnej od renesansu skłonności do unieważniania Starego, zarazem powie on metaforycznie o rewolucjach estetycznych, że "swój Nowy Testament długo jeszcze starały się one legitymizować mocą Starego Testamentu, przywłaszczając sobie tradycję antyku lub pewne jej pojęcia" (Jauss 25). Podobnie wydobywa nie tylko dążenie ku przyszłości wcielane przez linearny ciąg Nowego, ale przypomina o nawrotach Starego, kiedy to czas cykliczny wypiera linearność (Bukowski 63), na przykład w renesansie, co zresztą jego zdaniem nie podkopuje roli tej epoki jako poprzedniczki oświecenia - bo wspólne obu epokom (Bukowski 64) staje się przeświadczenie o konieczności przyjęcia istnienia obok uniwersalnego piękna antyku i piękna czasowego, relatywnego (beauté relative).

W każdym razie wydaje się już nie tylko kwestią dopowiedzenia, ale i umocnienia owej specyficznej, chwiejnej antynomii Jaussa, zaproponowane przez Gianniego Vattimo wyraźne połączenie dwu mitów z modernizmem i postmodernizmem. $\mathrm{Z}$ jednej strony bowiem pojawia się $\mathrm{u}$ niego mający charakter opozycji wobec faszyzmu czy dogmatyzmu liberalizm bądź rozumiany jako nie tyle powierzchowna moda, ile poważna propozycja poznawcza postmodernizm związany z mitem, w który autor wpisuje trzy przedstawiane przez siebie wyznaczniki narracyjności: A) w sferze ontologicznej archaizm kładący nacisk na zakorzenienie, tj. na przyczynę, a nie na skutek lub cel, a będący wyrazem niechęci wobec wyrastającej z metafizycznych ujęć naukowo-technicznej kultury, postrzeganej jako niszcząca związek "człowieka z samym sobą oraz z przyrodą" (Vattimo 2006a: 43) - co oznaczałoby również, że owa jedność człowieka z przyrodą w tym micie przeciwstawia się determinancie drugiego mitu, w którym Bóg wprowadza różnicę nie tylko między sobą a stworzeniem, ale także między człowiekiem a światem mu poddanym; B) w sferze poznawczej umiarkowany irracjonalizm bądź ograniczony racjonalizm - co wyklucza jednorodność poznania oraz C) w sferze kultury - relatywizm kulturowy, przeciwstawiający się uniwersalizmowi. W tym kontekście jednak dla niego samego (mogący zostać tu określony jako archaiczny):

mit nie jest jedynie prymitywną fazą, którą przekroczyła historia kulturalna, lecz raczej ciągle aktualną formą wiedzy bardziej autentycznej, wolnej od niszczącego wpływu fanatycznego upodobania nowoczesnej nauki, technologii i kapitalizmu do ujęć ilościowych i obiektywizujących (Vattimo 2006a: 44). 
Ciągle aktualna mityczna przeszłość zatem staje się wyznacznikiem postmodernistycznego myślenia.

Vattimo zarazem kieruje uwagę na drugi mit, który z kolei wiąże z rozumieniem nowoczesności jako epoki determinowanej nie przez archaizm wskazujący na czas przeszły (ale aktualny), lecz, jak to ujmuje, przez „futuryzm” sprawiający, że „bycie nowoczesnym staje się wartością, więcej, jedyną wartością fundamentalną, do której odnoszone są wszystkie pozostałe wartości" (Vattimo 2006b: 93, wyróżn. - G.V.). Tutaj pragnienie nowości - jako dającej możliwość osiągnięcia autentyczności - każe więc on postrzegać jako kierowane ku (mającej znaczenie dla czasu teraźniejszego) przyszłości. Podziela tym samym przekonanie Karla Löwitha (Significato e fine della storia, 1949), że istniejąc w postaci zsekularyzowanej, tj. pozbawionej pierwiastka transcendentalnego i opatrznościowego, nowoczesność pozostaje w dalszym ciągu spadkobierczynią wiary w postęp, zakotwiczonej w judeochrześcijańskiej linearnej (prostoliniowej) wizji historii, a tym samym w micie Boga (Vattimo 2006b: 95) i nowoczesnym historyzmie, będącym wyrazem sekularyzacji judeochrześcijańskiej teologii historii.

Trzeba jednak zaznaczyć, że wspomniany podział również przez tego autora nie jest postrzegany jako ostry. Zaznacza on, że jakkolwiek większa część nowoczesności zdominowana została przez oceniane przezeń mało przychylnie „mechaniczne umysły", czynne na płaszczyźnie nauki i techniki, to sztuka wcześniej niż te dziedziny (por. też Welsch 429-461) porzuciła metafizyczne zakorzenienie, stając się, by tak rzec, koniem trojańskim postmodernizmu wprowadzonym w mury modernistycznej Troi.

Tak więc zarówno w przypadku Jaussa (Stare i Nowe, tj. grecko-rzymskie i judeochrześcijańskie), jak i, znacznie wyraźniej, Vattimo (archaiczne, tj. wychodzące od przeszłości opartej na jedności z Naturą, i futurystyczne, tj. nastawione na nowość, która stanowi pogłos metafizyki) mamy do czynienia ze wskazaniem zakorzenionego w micie sporu, który jednak przyjmuje także postać splotu i węzła gordyjskiego, czyli współistnienia sygnującego nieuniknioną łączność i wzajemne żywienie się sobą obu orientacji poznawczych - tak zresztą, jak łączą się i żywią sobą w czasie teraźniejszym sygnujące je czasy.

Ale może najbardziej wyraziste przedstawienie tyleż sporu czy splotu, ile przeplatania się w czasie dwu orientacji poznawczych znajdziemy u Scotta Lasha, który (rozróżniając nowoczesność i modernizm - modernity i modernism) stwierdza:

Może sensowne byłoby [...] objąć renesans i oświecenie kategorią „wczesnej” nowoczesności, natomiast „późną” (czy przynajmniej późniejszą) nowoczesność zrównać zakresem z o wiele późniejszym pojawieniem się modernizmu estetycznego. Obie byłyby produktami ciągłego procesu modernizacji opartego na zasadzie kulturowego różnicowania (Lash 472). 
To różnicowanie jako wyznacznik procesu modernizacyjnego (które sam Lash wspiera nazwiskami od Georga W.F. Hegla, przez Talcotta Parsonsa, po Maxa Webera) uznać by tu można za pogłos hebrajskiego rozumienia świętości (godesz), która oznacza, że Bóg jest "oddzielony”, "całkiem inny” (od stworzenia) (Świderkówna 15). Byłaby to zatem - w perspektywie tego, co powiedzieliśmy wcześniej - próba pokazania, w jaki sposób mit nowoczesny, tj. Boga (tym samym pierwszą epokę „modernizacyjną" musielibyśmy usytuować już w czasach Starego Testamentu), lub jego zdesakralizowany odpowiednik dochodzą do głosu w epokach nienastępujących po sobie bezpośrednio (renesans, oświecenie, modernizm), a jednak mimo tych przerw ustanawiających "ciągły proces modernizacji”. Natomiast w konsekwencji takiego łączenia ze sobą epok ponad przedziałami musielibyśmy uznać także, że pozostające poza tak zaznaczoną (przerywaną) linią średniowiecze, barok, romantyzm, postmodernizm stają się elementami innego ciągu formacyjnego, mianowicie odróżnicowujących (na kształt zasady coincidentia oppositorum właściwej dla mitu Natury) epok „wczesnej ponowoczesności” (a jeszcze wcześniej „premodernizmu”, którego pierwsze przejawy wiązać by trzeba z boginiami, szczególnie z Boginią Matką, Boginią Ziemią itd., kolejne zaś np. z dionizyjskością).

W obu przypadkach zresztą za przyczynę owego przeplatania się epok można uznać wyczerpywanie się możliwości poznawczych zakotwiczonych w jednym lub drugim micie, a więc ujawnianie negatywnych aspektów towarzyszących tym epokom wzorców poznawczych, za jakie uznać można mity czy niesakralne ich odpowiedniki (paradygmaty). Lecz istotą tego przeplatania byłoby nie tylko wyczerpywanie się, ale i przywracanie czy odnawianie tych zdolności, jakby - co prawda nie w bezpośrednim następstwie - uświadamiające, że nic lepszego prócz tej nieuniknionej zmiany perspektyw nam nie pozostaje.

Natomiast w dalszym ciągu, jak i w przypadku Vattimo mówiącego wprost o micie jako o pewnej formie wiedzy (w tej sytuacji - innej dla modernizmu, innej dla postmodernizmu), możemy i tu wprowadzić związek modernizmu, opartego na różnicowaniu, które przesądzane jest przez czasowe ujęcie, z mitem nowoczesnym (Boga) i postmodernizmu, opartego na odróżnicowywaniu, oznaczającym przestrzenne ujęcie rzeczywistości - z mitem archaicznym (Natury). Różnicowanie powiązać by trzeba zatem z wyborem, jaki pociąga za sobą (jako wieczna Forma) Jeden² Bóg (Kopaliński 122), a odróżnicowanie - ze zbiorem, jaki wprowadza Pełnia (Wszystko) czy Prajednia Natury.

W punkcie wyjścia stawiamy więc dwa mity (Wiśniewska 2013: 9-52; Wiśniewska 2015: 81-91) jako pozwalające na interpretację rzeczywistości poznawcze ujęcia

2 Jeden to, przypomnijmy, liczba uznawana przez pitagorejczyków za emblemat rozumu, na Bliskim Wschodzie - za najdoskonalszą, bo reprezentująca byt (w opozycji do niebytu, tj. zera), wyjściową dla wszystkich innych jako jej wielokrotności, za przedstawiającą Stwórcę, co podejmuje biblijny prorok Zachariasz, powiadając: „W owym dniu Bóg będzie Jeden i imię jego będzie Jeden” (Za 14, 9). W marzeniu sennym reprezentuje raj poprzedzający dualizm dobra i zła. 
oparte na określonym w odniesieniu do rzeczywistości traktowaniu (tj. zacieraniu bądź eksponowaniu) odmiennych jej aspektów unaocznianych poprzez kategorie czasu lub przestrzeni. Mit przy tym rozumiemy jako absolutyzację określonego sposobu widzenia przesądzonego przez jedną z tych kategorii, paradygmat zaś jako wyraz poznawania, w którym jedna $z$ tych kategorii dominuje nad drugą. Pierwsze z tych absolutyzujących ujęć, mit archaiczny, wskazujący na pierwotne źródło Natury, można uznać za zakotwiczający swoją opcję poznawczą w (odnawialnej, cyrkularnej) przeszłości czasu niejako wchłoniętego w jej (Natury) przestrzeń (czy też czasoprzestrzeń) stanowiącą Pełnię (Wszystko), lecz i za skazany jednocześnie na Chaos ( $w$ czasie niebędącym wyborem przesądzonym przez linię prostą lecz przeciwnie, okazującym się zbiorem nawrotów). Drugie z nich natomiast, mit nowoczesny, wskazujący na Boga jako cel, można uznać za zakotwiczający swoją opcję poznawczą $w$ prostoliniowym wymiarze czasowym zmierzającym ku skończonej przyszłości (Apokalipsa), poza którą czas uzyskuje postać doskonałą (Bóg jako wieczność) i absolutną (Forma - Jedno), poprzez ten wybór zresztą eliminując przestrzeń, uzyskującą wymiar Pustki (nicość, zerowy wymiar). Natomiast odpowiadające tym mitom poznawcze wzorce niesakralne, nieabsolutyzujące ani wymiaru czasowego, ani przestrzennego zarówno w ich pozytywnym, jak i w negatywnym wymiarze, wprowadzają mimo wszystko w zamian określoną wariantowość czasu i przestrzeni. W przypadku analogicznego do mitu Natury paradygmatu kołowego nie tylko przestrzeń zostaje oparta na zasadzie coincidentia oppositorum, ale i czas - włączony do jej wymiarów - jawi się jako skomplikowany, bo zakrzywiony (cyrkularny), natomiast w przypadku analogicznego do mitu Boga paradygmatu linearnego - nie tylko czas jest prostoliniowy, ograniczony początkiem i końcem, ale i poddana presji owej prostoliniowości, uproszczona z kolei zostaje przestrzeń, uzyskując postać hierarchiczną.

Dzięki tym dwu typom wzorców poznawczych (w ich wersji sakralnej, mitycznej lub niesakralnej, paradygmatycznej) uzyskujemy łączność między zdominowanymi przez mit jako zupełnie zasadniczą narrację początkami kultury a dniem dzisiejszym - łączność pokazującą trwałość wspomnianych wzorców poznawczych opartych na bezprzymiotnikowych (Forma, Chaos, Pełnia, Pustka) lub (z grubsza rzecz ujmując) "przymiotnikowych” wersjach czasu (prostoliniowy lub cyrkularny) i przestrzeni (hierarchiczna lub paradoksalna, oparta na zasadzie coincidentia oppositorum).

Odwoływanie się do tych dwu odmiennych wzorców pozwala zarazem na zrozumienie swoistości epoki lub formacji kulturowej - swoistości uzmysławiającej tyleż obietnicę, ile nieuchronne zagrożenie płynące ze skupienia się na jednej perspektywie. Przyszłość i przeszłość, obiektywność prawdy i relatywność kulturowa, racjonalność odsuwająca irracjonalność i swoista racjonalna irracjonalność (połączona $\mathrm{z}$ racjonalnością irracjonalność), stanowiące $\mathrm{w}$ tym ujęciu pochodne rozdzielenia-różnicowania (począwszy od człowieka i Boga) lub połączenia-zrównania 
(począwszy od człowieka i Natury), wprowadzają zatem nie opcję eliminacji, ale kompleksowości perspektyw, których hasłem wywoławczym, w każdym zresztą przypadku, staje się postulatywna autentyczność poznania - tyle że jest to autentyczność w określonym czasie lub miejscu, jak się okazuje, stopniowo lub nagle wyczerpująca swoje możliwości i domagająca się reaktywowania odmiennej opcji poznawczej. Mogąca budzić zniechęcenie nietrwałość owych odmiennych postaci autentyczności poznania zrekompensowana zostaje jednak nie tylko trwałością wyznaczaną przez łączność skrajnych punktów, ale i przez ich swoistą, jeśli tak to można ująć, "przerywaną ciągłość” uobecniającą tak czas linearny, jak i kołowy.

W koncepcji Lasha wielkie czasowe skale epok traktowane w kategoriach różnicowania i odróżnicowywania znajdują analogię również w postrzeganiu przestrzeni kultury i twórczości ludzkiej znajdującej przełożenie na mniejszą skalę reprezentowaną przez samego człowieka. Uzyskują one postać traktowanych jako typy idealne (a pochodnych od Lyotardowskiego rozróżnienia dyskursu i figury) bądź to „dyskursywnej wrażliwości modernistycznej”, bądź to „figuralnej wrażliwości postmodernistycznej" (Lash 475).

Oto wyznaczniki tych typów (rzymskimi cyframi oznaczam te wpisujące się w dyskurs modernistyczny, odnoszony tu przeze mnie do mitu Boga, arabskimi - te wpisujące się we wrażliwość postmodernistyczną, odnoszoną tu do mitu Natury):

I) Oddanie pierwszeństwa (duchowym) słowom przed (zmysłowymi) obrazami można uznać za przejęcie przez oryginalnego z założenia twórcę kultury duchowej roli Boga stwarzającego za pomocą słowa zewnętrzny i różny od siebie świat (w tym przypadku - fikcji literackiej). Podobnie jak w przypadku mitu nowoczesnego Bóg jest diametralnie inny jako czysto duchowy Byt sytuujący się ponad (mniej lub bardziej materialnym, wpisującym się pod tym względem $\mathrm{w}$ przestrzenną hierarchię) stworzeniem i stanowi przy tym „Jeden” wzorzec-Formę, tak i w twórczości ujawnia się hierarchia twórcy i dzieła, twórcy i odbiorcy itd., nie wspominając o tym, że dzieło przybiera postać zamkniętej czy skończonej w (prostoliniowym) czasie formy jako stałego efektu, zdecydowanie różnego w swej semantyce od innych.

1) Wrażliwość raczej wizualna (i pociągająca zresztą za sobą, jak to ujmuje Lash, swoisty naturalizm, kierujący, jak przyjmujemy, uwagę w stronę mitu Natury) niż literacka pozwala, idąc za Françoisem Lyotardem, uznać Lashowi za istotne odróżnicowanie semiotyki dzięki obrazom oznaczającym przez podobieństwo (niezakładającym więc eliminacji elementów z pewnego punktu widzenia ocenianych jako negatywne czy wyboru pozytywnych ze względu na jakieś kryterium, na przykład dydaktyczne czy etyczne) i stąd mniejszą ich odmienność od przedmiotów odniesienia (jeśli nie równość) niż ta, jaką wprowadza język. Można by powiedzieć, że analogicznie do sytuacji autokreacyjnej Natury czy Bogini, z której wnętrza i ciała powstaje świat, także Nietzscheańskie, płynące z dionizyjskości, "pisanie krwią" 
(Nietzsche 1913: 47) konstytuuje koncepcję twórczości postrzeganej jako proces cielesny, a nawet ból, cierpienie i niszczenie ciała. Przywoływana przez Lasha Susan Sontag domaga się na przykład traktowania dzieła sztuki jako przedmiotu zmysłowego nieróżniącego się zbytnio od przedmiotu odniesienia, bo stanowiącego niejako jego przedłużenie, co, jak można przyjąć, pociąga za sobą swoiste odtwarzanie przestrzeni Prajedni, charakterystycznej dla mitu Natury, w której zamiast stałej Formy zasadniczą rolę odgrywa niekończąca się w czasie kołowym metamorfoza.

II) Podobną rolę, jaką odgrywa stałe i dane zewnętrznie prawo Boskie w kształtowaniu wyboru Jednego, w tego typu kulturze pełnią jakości formalne obiektów kulturowych, domagające się realizowania określonych (zewnętrznych) zasad, kanonów, reguł nie tylko zmuszających do wydobywania w owych obiektach tego, co główne i zasadnicze, ale i wpisywania ich w określone klasyfikacje (gatunków, rodzajów, prądów, stylów itd.), co poddaje je również imperatywowi stałości. Lash na przykład przedstawia kino modernistyczne jako dyskursywne (w sensie Foucaultowskim, tzn. wykrystalizowanym w Archeologii wiedzy), czyli kierujące uwagę na reguły, normy i konwencje samego przedstawiania (jak w Inaczej niż $w$ raju Jima Jarmuscha). Podobnie (powołując się na Theodora Adorna, Clementa Greenberga czy Richarda Wollheima) przypisuje malarstwu modernistycznemu zdolność kierowania uwagi przede wszystkim na powierzchnię obrazu i jej możliwości estetyczne.

2) Mit Natury dewaluuje natomiast na przykład w odpowiadającym mu spoleczeństwie matriarchalnym prawo (co niekoniecznie można uznać za element pozytywny), zamiast niego wskazując na miłość, równość i wolność (Fromm 18). Dewaluację formalizmów w kulturze może najwyraźniej uwydatnia zaś praktyka surrealistyczna - których strategię Walter Benjamin nazywa surrealistyczną alegorią (za: Lash 484) - przynosząca łączenie wybranych stałych, a właściwie spetryfikowanych, lub nieznaczących (czyli w poprzedniej strategii odsuniętych na margines) elementów, by poprzez zetknięcie mniej lub bardziej odległych znaczeń wytworzyć jednocześnie impet, a więc ruch, i point sublime, czyli (opartą na jedności przeciwieństw, jak inaczej można nazwać kondensację różnic) poetyzację banalności, rodzaj świeckiej iluminacji (Giorgio Chirico, Max Ernst, Salvador Dali) odnoszącej się tyleż do życia i miłości, ile do sztuki. Ale również postmodernistyczne kino „transgresyjne", które uprzywilejowuje spektakl, wtrąca widza w nomadyczny tryb odbioru, z wielką szybkością wciąga go do wnętrza rzeczywistości filmowej, w której znaleźć można mieszaninę gatunków, niepodlegającą jakimś normom.

III) Mogące zostać uznane za pochodną Jednej (czystej) Formy zmierzanie do wyłonienia czystych form w sztuce dystansuje widza od obiektu, autora od jego dzieła, praktykę od teorii, sztukę wysoką od niskiej, to, co artystyczne, od tego, co nieartystyczne, a kulturowe od tego, co niekulturowe - czyli promuje mechanizm różnico- 
wania, przesądzony, jak można przyjąć, przez będącą pochodną oddzielenia „innego" Boga hierarchię w przestrzeni czy początek i koniec w czasie odpowiadające za powstawanie tworów opartych na tożsamości i homogeniczności.

3) Działanie poprzez lokowanie pragnienia widza w obiekcie kulturowym, odmowa oddzielenia publiczności od przedstawienia (performace), autora od jego dzieła czy też literatury od teorii, sztuki wysokiej od popularnej, a także tego, co właściwie kulturowe od tego, co właściwie społeczne, oraz traktowanie sztuki jak przedłużenia życia stwarza sytuację podobną do tej, jaką ustanawia (przedstawiana z brodą) androgyniczna Kybele lub bogowie zarówno wewnętrznie, jak i zewnętrznie zdeterminowani przez zasadę coincidentia oppositorum, sytuowani nie na zewnątrz, lecz wewnątrz świata i stanowiący jego siły wprzęgnięte w nieustanne metamorfozy, które powodują wyłanianie tworów hybrydycznych czy polimorficznych.

IV) Jak przyjmuje Lash, język jest ustrukturowany, tj. nastawiony na artykułowanie i różnicowanie (przeciwieństwo kondensacji) oraz selekcję i kombinację, kanalizujące energię przy pomocy reguł i przeszkód, będących wynikiem reakcji obronnych ego, co możemy tu potraktować jako analogię do (stałego) prawa Boga-Formy, domagającego się wyboru Jednego na różnych płaszczyznach (od jednego Boga i Księgi, przez religię, naród, miasto, małżeństwo, po określone życie i tożsamość), czego rezultatem w tym przypadku byłby określony, na przykład realistyczny, kanon. Przypisanie zasadniczej wagi semiotyce i znaczeniom tekstów kultury (stąd "realistyczna” estetyka znaczenia i formalizm modernistyczny) akcentuje rolę interpretacji jako sposobu wyłaniania pewnego stabilizującego porządku opartego na wydobyciu na powierzchnię tego, co uważa się za ważne czy istotne, a tym samym na hierarchizacji w przestrzeni i nadaniu całościowej spójności w czasie. Przywoływana przez Lasha Sontag uważa to za przejaw hipertrofii intelektu, a przez to zubożenia przedmiotu zainteresowania; wspomniane podejście jednak wpisuje się w kategorie czasu i przestrzeni charakterystyczne dla paradygmatu linearnego, odpowiadającego mitowi nowoczesnemu.

4) Niekoncentrowanie się na tym, co tekst znaczy, ale na tym, jak mocno oddziałuje (dodajmy: na emocje), dochodzi do głosu, gdy na przykład Sontag odrzuca symbolizm na rzecz „impetu” Pounda, a teatr dialogu, inteligencji czy dydaktyki Brechta na rzecz Artaudowskiego teatru okrucieństwa (czy też gestu, zmysłów $i$, co nie jest $w$ tym przypadku bez znaczenia, magii i rytuału), gdzie centralne miejsce zajmuje ruch ciała (jedno i drugie wskazuje na mit Natury jako punkt wyjścia). Tym samym zmierza ona w kierunku estetyki nie znaczeń, lecz ruchu rozumianego jako moc kosmiczna oraz (zdeseksualizowanego, poniekąd pozbawionego organów) ciała jako narzędzia percepcji i odczuwania - przy jednoczesnym pominięciu języka, choć, trzeba to podkreślić, nie siły auratycznej samego dźwięku i nie, na przykład, mowy inkantacyjnej (przypomnijmy, że łacińskie incantatio znaczy 'czarowanie, czary'). Czary i magia wprowadzają tutaj zamiast związków przyczyno- 
wo-skutkowych - charakterystycznych dla czasu linearnego - analogie, które wiążą ponad różnicami płaszczyzn (tak zatem ujawnia się zasada coincidentia oppositorum w poznaniu) nie mniej niż wskazują na kołowość zjawisk.

V) Ukonstytuowanie racjonalistycznej wizji kultury oznacza, że jej znakiem staje się "wykształcone ucho", to znaczy zmysł poddany rygorom formy, która domaga się wyboru, nastawiony na słuchanie (odbiór tego, co zostaje poświadczone autorytetem „twórcy”), przynoszące wiedzę niebezpośrednią. Stąd bierze się logocentryzm.

5) Przeciwstawienie się racjonalistycznym (czy „dydaktycznym”) wizjom kultury i odwołanie się do pragnienia czyni znakiem rozpoznawczym tej postawy dające bezpośrednią wiedzę "dzikie oko”, którego mobilność przypomina, według Lyotarda, „niepowstrzymaną mobilność kateksji”, tj. osadzenia i inwestowania we „wspomnienia percepcyjne”, fantazje, halucynacje nieprzekształcające zewnętrznej rzeczywistości, natomiast zdolnej do kondensacji sprzeczności (coincidentia oppositorum) w świecie wewnętrznym.

VI) Dyskursywna wrażliwość modernistyczna jest raczej wrażliwością ego niż id, a więc świadomość zajmuje hierarchiczną pozycję nad nieświadomością. Przypomnieć więc warto, że w micie nowoczesnym nawet anioły to czyste Inteligencje, a nawet "serce" pojawiające się u św. Pawła jako kardia to właściwie tłumaczenie hebrajskiego słowa „umysł” lub „duch”, zaś cordatus po łacinie to człowiek nie uczuć, lecz rozsądku (Lewis 111).

6) Figuralna wrażliwość postmodernistyczna promuje rozciągnięcie procesu pierwotnego (kategoria Freudowska) na domenę kultury, ponieważ proces wtórny do pierwotnego ma się jak język do obrazu. Ta erupcja podmiotu pierwotnego (nieświadomość wpisuje się w mit Natury) prowadzi do powstania przeciwstawiającego się sztywnemu umiejscowieniu podmiotu nomadycznego, jak go nazywają Gilles Deleuze i Felix Guattari, czego walor polityczny ujawnia się w umożliwieniu istnienia alternatywnych form konstruowania tożsamości i tolerancji dla związanej z tym „różnicy” (coincidentia oppositorum).

W przytoczonym zestawieniu cech wyznaczających dwie odmienne formacje kultury (modernistyczną i postmodernistyczną) trudno jednak byłoby mówić o jakiejś przewadze którejś z nich. Słowo i obraz, duch i ciało, ego i id, rozum i zmysły lub emocje, stałość i zmienność (impet, ruch), prawo (granice) i wolność, czystość (tożsamość) i polimorficzność (tu: Nietzscheańska „samość”), realizm (naturalizm) i metafizyka, hierarchia i kondensacja sprzeczności, zamknięcie (w linearnym czasie) i otwarcie (cyrkularność), krótko mówiąc mit Boga (nowoczesny) i mit Natury (archaiczny), to perspektywy poznawcze, które wprowadzają pewne "gramatyki poznania", równie jak tworzenia, ale żadna nie jest wyczerpująca, zaś każda 
z nich, przynosząc swój zakres „wiedzy”, może wchodzić z drugą w różne konfiguracje, pozwalając na ujęcie rzeczywistości także na styku czy przecięciu się ich zakresów. To samo dotyczyć musi pociągniętych ku nim dwu długich (choć nie nieprzerywanych) ciągów/linii formacyjnych wyprowadzonych z mitów, jak uważają niektórzy, pełniących rolę wiedzy niewyspecjalizowanej, obejmującej wszystkie te zakresy, które później przekształciły się w samodzielne dziedziny kultury - od nauki po sztukę i filozofię. Klasyczna, wyliczająca definicja kultury Edwarda Burnetta Tylora określa kulturę (cywilizację) - jako obejmującą wiedzę i wierzenia, sztukę i religię, moralność i prawo, zwyczaje i zdolności oraz nawyki, nabyte przez człowieka jako członka społeczeństwa ${ }^{3}$ - jako całość złożoną z wielości graniczących z sobą poszczególnych dziedzin, pośród których jednak nie zostaje wymieniony mit. Choć Ernst Cassirer włącza już ten ostatni do swojej, również wyliczającej definicji kultury (Cassirer 132), być może jednak należałoby się zastanowić nad uznaniem mitu raczej za narzędzie poznania, dzięki któremu możliwe się staje porównawcze odnajdywanie w owych dziedzinach ich wspólnego mitycznego jądra. Zresztą podwójnego jądra, zdeterminowanego przez dwa mity. Jest zatem znamienne, że Georg Steiner w swojej "gramatyce tworzenia" (odnoszącej się zresztą tyleż do poezji czy muzyki, ile do matematyki czy metafizyki), którą można by zresztą uznać za lustrzane odbicie interesującej nas tu "gramatyki poznania”, stwierdzi, właściwie dokładnie wpisując się w charakterystykę modernizmu i postmodernizmu, jaką przedstawił Lash, choć mówi o mitach: „Jeśli hebrajska opowieść o stworzeniu jest retoryczna, to dawne kosmogonie greckie są «erotykiem»" (Steiner 36).

Natomiast wszystkie trzy wcześniej przytoczone tu koncepcje zdają się otwierać drogę do zastanowienia się nad opisem rzeczywistości kulturowej jako skomplikowanej całości budowanej w istocie ze stosunkowo prostych składowych, mianowicie wzorców poznawczych skonstruowanych na bazie określonych wersji czasu i przestrzeni, które stanowić mogą podstawę porównywania, uzasadnioną logiką podstawowych całości, jakie stanowią mity i paradygmaty, gdyż - jeszcze raz odwołam się do Steinera - „Ledwie zamaskowane pojawiają się na nowo archaiczne konstrukcje religijno-mitologiczne" (Steiner 18), możliwe do wskazania zarówno w pismach Marksa, jak i w koncepcjach Freuda. Przy tym, ponieważ mity (i paradygmaty) tworzą kompleksowy układ kategorii czasu i przestrzeni, $\mathrm{w}$ rezultacie przydatne mogą być na różnych poziomach opisu rzeczywistości (np. utworu jako całości, a nie tylko kultury jako całości). Choć to już kwestia do rozpatrzenia przy innej okazji.

3 „Kultura, czyli cywilizacja w szerokim etnograficznym sensie, jest złożoną całością, która obejmuje wiedzę, wierzenia, sztukę, moralność, prawo, obyczaje oraz wszelkie inne zdolności i nawyki zdobyte przez człowieka jako członka społeczeństwa" (Nowicka 47). 


\section{BIBLIOGRAFIA}

Bukowski, Piotr. "Genealogia procesu literackiego modernizmu H. R. Jaussa”. Odkrywanie modernizmu. Red. R. Nycz. Kraków: Universitas, 2004. S. 60-70.

Fromm, Erich. Mitość, płeć i matriarchat. Przeł. Beata Radomska, Grzegorz Sowiński. Poznań: Dom Wydawniczy Rebis, 2002.

Jauss, Robert Hans. „Proces literacki modernizmu od Rousseau do Adorna”. Przeł. Piotr Bukowski. Odkrywanie modernizmu. Red. R. Nycz. Kraków: Universitas, 2004. S. 21-59.

Kopaliński, Wladysław. „Jeden”. Stownik symboli. Warszawa: WP, 1990.

Krokiewicz, Adam. „Studia orfickie”. Studia orfickie. Moralność Homera i etyka Hezjoda. Warszawa: Aletheia, 2000. S. 5-78.

Lash, Scott. „Dyskurs czy figura? Postmodernizm jako system oznaczania”. Przeł. Paweł Wawrzyszko. Odkrywanie modernizmu. Red. R. Nycz. Kraków: Universitas, 2004. S. 471- 506.

Lewis, Clive Staples. Odrzucony obraz. Wprowadzenie do literatury średniowiecznej i renesansowej. Przeł. Witold Ostrowski. Instytut Wydawniczy PAX. Warszawa 1986.

Nietzsche, Fryderyk. Narodziny tragedii, czyli hellenizm i pesymizm. Przeł. Leopold Staff. Warszawa: Nakładem Jakuba Mortkowicza, 1907.

Nietzsche, Fryderyk. Tako rzecze Zaratustra. Ksiażka dla wszystkich i dla nikogo. Przeł. Wacław Berent. Warszawa: Nakładem Jakuba Mortkowicza, 1913.

Steiner, Georg. Gramatyki tworzenia. Na podstawie wygłoszonych w roku 1990 wykładów imienia Gifforda. Przeł. Jerzy Łoziński. Poznań: Wydawnictwo Zysk i S-ka, 1991.

Nowicka, Ewa. Świat człowieka - świat kultury. Warszawa: PWN, 2006.

Świderkówna, Anna. Rozmowy o Biblii. Warszawa: PWN, 1996.

Vattimo, Gianni. „Mit powtórnie odkryty”. Społeczeństwo przejrzyste. Przeł. Magdalena Kamińska. Wrocław: Wyd. Naukowe Dolnośląskiej Szkoły Wyższej Edukacji TWP we Wrocławiu, 2006.

Vattimo, Gianni. „Struktura rewolucji artystycznych”. Koniec nowoczesności. Przeł. Monika Surma-Gawłowska, wstęp Andrzej Zawadzki. Kraków: Universitas, 2006. S. 83-101.

Vernant, Jean-Pierre. Mit i religia w Grecji starożytnej. Przeł. Krzysztof Środa. Warszawa: Fundacja Aletheia, 1998.

Welsch, Wolfgang. „Narodziny filozofii postmodernistycznej z ducha sztuki modernistycznej”. Przeł. Jan Balbierz. Odkrywanie modernizmu. Red. R. Nycz. Kraków: Universitas, 2004. S. 429-461

Wiśniewska, Lidia. „Metoda mityczno-paradygmatyczna w komparatystyce mitograficznej”. Projekt komparatystyki mitograficznej. Komparatystyka między Mickiewiczem a dniem dzisiejszym IV. Red. L. Wiśniewska. Bydgoszcz: Wydawnictwo Uniwersytetu Kazimierza Wielkiego, 2015. S. 63-91.

Wiśniewska, Lidia. „Mity i paradygmaty wobec dziedzin kultury i epok, czyli komparatystyka wieloaspektowa". Mity i motywy w perspektywie komparatystycznej. Komparatystyka między Mickiewiczem a dniem dzisiejszym III. Red. L. Wiśniewska. Bydgoszcz: Wydawnictwo Uniwersytetu Kazimierza Wielkiego, 2013. S. 9-52. 